\title{
PERSONAL SKETCH OF HON. HIRAM PRICE, OF
} DAVENPORT, IOWA.

BY THE EDITOR.

Hon. Hiram Price, of Davenport, Iowa, was born on the loth of January, 1814, in Washington County, Pennsylvania. At five years of age, he was taken to Mifflin County; and three years after, to Huntington County, in the old Keystone State, whence, in the Autumn of 1844, he removed to Davenport, which has ever since been his place of residence.

Of his parentage and youthful history the writer is not informed.

On coming to Davenport, his capital in trade, as a Merchant, was only one hundred dollars. But his business talent, his stern integrity, his resolute perseverance, and entire temperance made him successful in accummulating a handsome fortune, from this small pecuniary beginning, continuing his mercantile pursuit only until 1848.

In 1847, he was elected the first School Fund Commissioner of Scott County, which office he held for nine years.

In 1848, he was chosen Recorder and Treasurer of Scott County, filling that position for eight years, and then declining a re-election.

In the cause of Total Abstinence from all spiritous and fermented drinks, or Temperance as understood by strict interpreters of the pledge, Mr. Price has been an early and consistent actor and exemplar. He was one of those who organized the Grand Division of the Sons of Temperance for the State of Iowa, in 1848; and was chosen the first grand Worthy A. ; and afterwards, Grand W. Patriarch of the State Division, having, the year before organized a Division of the Sons of Temperance in Davenport, of which he was the first Worthy Patriarch. In 1854, he was elected President of the Maine Law Alliance, with which and the State Temperance Society, he labored successfully for the object contemplated and ultimately attained,-a Prohibitory Liquor Law for Iowa.

Mr. Price was connected from the first, with the enterprise of the Mississippi and Missouri Railroad, now in so successful progress 
toward the Pacific Ocean, procuring the right of way along the route from Davenport to Council Bluffs, and raising up friends for the great undertaking. He, with others, foresaw, that this was the grand central route through Iowa. For several years, he was Treasurer of the Corporation having in charge its construction, as well as Director of the same, being one of its original corporators.

Mr. Price was Treasurer of Scott County Bible Society for the years 1851, 1852, 1856 and 1857, and also President for 1854 and 1855.

His connection, also, with the Branch of the State Bank at Davenport, shows in what confidence he is held as a business man.

Mr. Price is a member of the Methodist Episcopal Church, and a firm supporter of religion and all benevolent institutions of the day.

In 1862, he was the successful candidate for Representative to the Congress of the United States, in the district where Davenport is located ; and by a large majority, now has a seat as Representative from Iowa. His personal purity of character, unbending integrity, and tenacity of the right, will give him a high position on the floor of the House.

Mr. Price, as his portrait, in this number, indicates, has a look of decided purpose, a cheerful countenance, a light complexion, a trim stature of over middle height, and is agreeable and social in his manners, with that constant flow of good feeling, which temperance, early rising, and activity are adapted to inspire. Without the hurtful spirit of ambition to be what one is not, he has the true humility of nature's nobleman, to let others speak well of him, but not to seek elevation. In short, he is one of the worthy men of the age, whose merits and not facticious circumstances, have raised to place and consequence in society.

\section{CHICAGO HISTORICAL SOCIETY.}

This Society seems, by reports in the papers of Chicago, to be prospering. In the heart of a great and growing commercial town, the New York of the Northwest, it has many advantages for the accumulation of books and cabinet curiosities. We would be pleased to renew correspondence and exchange. 
Copyright of Annals of Iowa is the property of State of Iowa, by \& through the State Historical Society of Iowa and its content may not be copied or emailed to multiple sites or posted to a listserv without the copyright holder's express written permission. However, users may print, download, or email articles for individual use. 